\title{
EDUKASI TEKNOLOGI PANEL SURYA SEBAGAI SUMBER ENERGI LISTRIK AQUAPONIK DI KELURAHAN TANJUNG PALAS KOTA DUMAI
}

\author{
Bobby Demeianto ${ }^{1)}$, Rizqi Ilmal Yaqin ${ }^{2)}$, Muhammad Nur Arkham ${ }^{3)}$, Bambang Imawan' ${ }^{4)}$, Kenny \\ Bastian $^{5)}$, Iwed Mulyani' \\ ${ }^{1)}$ Program Studi Permesinan Kapal, Politeknik Kelautan dan Perikanan Dumai \\ 2)*Program Studi Permesinan Kapal, Politeknik Kelautan dan Perikanan Dumai, r.ilmalyaqin@ politeknikkpdumai.ac.id \\ 3) Program Studi Perikanan Tangkap, Politeknik Kelautan dan Perikanan Dumai \\ 4) Jr. Officer CSR, PT Pertamina RU II Dumai \\ 5) Community Development Officer, PT Pertamina RU II Dumai \\ 6) Community Development Officer, PT Pertamina RU II Dumai
}

\begin{abstract}
Abstrak
Sumber energi listrik merupakan salah satu komponen pokok dalam kehidupan sehari-hari. Berkembangnya teknologi saat ini menuntut untuk semua masyarakat untuk dapat memanfaatkan energi terbarukan salah satunya energi matahari. Panel surya merupakan salah satu mesin konversi energi yang dapat menghasilkan energi listrik. Masyarakat pesisir yang memiliki keadaan yang melimpah akan sumber energi matahari yang dapat dimanfaatkan panel surya sebagai energi listrik alternatif pada sistem aquaponik yang telah dibangun. Masyarakat Kelurahan Tanjung Palas Kota Dumai mayoritas memiliki profesi nelayan. Sehingga perlu adanya tambahan pemasukan ekonomi selain berprofesi nelayan. Disisi lain masyarakat masih belum paham akan pengoperasian dan perawatan panel surya karena masalah pengetahuan. Oleh karena itu edukasi dan instalasi panel surya sebagai sumber listrik aquaponik merupakan alternatif solusi yang ditawarkan untuk masyarakat. Kegiatan edukasi panel surya sebagai sumber listrik aquaponik dilakukan kerja sama dengan CSR PT Pertamina RU II Dumai dengan Politeknik Kelautan dan Perikanan Dumai. Hasil dari kegiatan ini yaitu tingkat pemahaman peserta dari per kategori selalu meningkat. Kategori pengetahuan meningkat dari $39 \%$ peserta menjadi $93 \%$ peserta, kategori pengoperasian meningkat dari $14 \%$ peserta menjadi $94 \%$ dan kategori perawatan meningkat dari $14 \%$ peserta menjadi $95 \%$ peserta. Selain itu tingkat kepuasan dari peserta menunjukkan 25\% peserta sangat puas dan $75 \%$ peserta puas dari kegiatan ini. Rekomendasi hasil kegiatan yang telah dilakukan yaitu perlu ada kegiatan tindak lanjut agar masyarakat lebih dapat memanfaatkan panel surya sebagai energi listrik alternatif.
\end{abstract}

Kata Kunci: Panel Surya, Energi Listrik, Aquaponik, Dumai

Abstract
The source of electrical energy is one of the main components in everyday life. The development
of technology today requires all people to be able to take advantage of renewable energy, one of
which is solar energy. The solar panel is an energy conversion machine that can produce electrical
energy. Coastal communities have an abundance of solar energy sources that can be utilized by
solar panels as alternative electrical energy in the aquaponics system that has been built. The
majority of the people of Tanjung Palas Village, Dumai City, are fishermen. So that there is a need
for additional economic income besides being a fisherman. On the other hand, the community still
does not understand the operation and maintenance of solar panels due to knowledge problems.
Therefore education and the installation of solar panels as a source of aquaponic electricity are
alternative solutions offered to the community. The educational activity of solar panels as a source
of aquaponic electricity is carried out in collaboration with CSR PT Pertamina RU II Dumai with
the Dumai Marine and Fisheries Polytechnic. The result of this activity is that the level of
understanding of participants from per category always increases. The knowledge category
increased from $39 \%$ of participants to 93\% of participants, the operating category increased from
14\% of participants to 94\% and the care category increased from 14\% of participants to 95\% of


participants. In addition, the level of satisfaction of the participants shows that $25 \%$ of participants are very satisfied and $75 \%$ of participants are satisfied with this activity. Recommendations for the results of activities that have been carried out are that there is a need for follow-up activities so that the community can better utilize solar panels as alternative electrical energy.

Keywords: Solar Panel, Electrical Energy, Aquaponic, Dumai

\section{PENDAHULUAN}

Energi listrik merupakan salah satu faktor yang memiliki peranan penting dalam perekonomian sebuah negara. Fenomena kenaikan kebutuhan energi listrik di sebuah negara disebabkan adanya perkembangan teknologi pada industri dan gaya hidup manusia (Stevović et al., 2019). Indonesia adalah konsumen energi terbesar di Asia Tenggara dengan terhitung lebih dari 36\% permintaan seluruh negara Asia Tenggara (MEMR (Ministry of Energy and Mineral Resources of the Republic of Indonesia), 2016). Pemerintah Indonesia telah menyatakan bahwa target kebutuhan energi listrik Indonesia 2019 mencapai 35GW. Namun, Dewan Energi Nasional menyatakan Indonesia hanya mampu memenuhi kebutuhan energinya hanya 19GW (Mcneil et al., 2019). Lebih dari 50\% kebutuhan utama energi listrik di Indonesia bersumber dari bahan bakar fosil, meskipun indonesia merupakan salah satu negara yang memiliki potensi besar untuk energi terbarukan (Tarigan et al., 2014). Penggunaan bahan bakar fosil sebagai sumber energi listrik menyebabkan peningkatan konsentrasi atmosfer gas rumah kaca yang menyebabkan kenaikan suhu global, mencarinya es di kutub, perubahan iklim dan peningkatan permukaan air (Pringle et al., 2017).

Dumai merupakan salah satu kota di Indonesia yang dekat dengan garis khatulistiwa. Hal tersebut menyebabkan kota Dumai memiliki intensitas energi dari matahari yang cukup besar. Kota Dumai memiliki potensi energi matahari sekitar 4,43 $\mathrm{kWh} / \mathrm{m}^{2} /$ hari (Jufrizel \& Irfan, 2017). Potensi energi yang melimpah di Indonesia terutama di Kota Dumai dapat digunakan sebagai sumber energi listrik terbarukan dengan memanfaatkan panel surya. Penggunaan sumber energi matahari sebagai energi listrik berupa teknologi panel surya membantu mengurangi emisi gas $\mathrm{CO}_{2}$. Sumber energi listrik dari energi matahari dapat memenuhi kebutuhan listrik untuk beberapa negara (Pavlović et al., 2013) baik untuk kebutuhan listrik di industri maupun rumah tenaga. Penggunaan panel surya di Indonesia sebagai kebutuhan energi listrik sudah banyak digunakan. Salah satu penggunaan panel surya pada kebutuhan listrik pada pemeliharaan tanaman dengan memanfaatkan budidaya perikanan atau aquaponik (Dwiyaniti et al., 2020; Hindarti, 2018). Penggunaan panel surya diperuntukkan untuk alat atau komponen pendukung sirkulasi air pada aquaponik tersebut.

Indonesia dengan topografi, posisi, dan populasi penduduk yang menyebar dengan tingkat perekonomian yang berbeda-beda ditambah memiliki iklim tropis tentu sangat sesuai untuk pemanfaatan panel surya sebagai energi terbarukan (Ekawita et al., 2020; Umar \& Yaqin, 2020) untuk penggunaan aquaponik. Sebagaimana keadaan Kota Dumai yang merupakan daerah pesisir pulau Sumatera yang memiliki posisi dan keadaan yang baik untuk penggunaan solar panel. Berkaitan dengan pemanfaatan energi terbarukan, masyarakat Indonesia khususnya masyarakat Kota Dumai yang memiliki tingkat ekonomi tertentu masih minim pengetahuannya tentang solar panel. Masyarakat Kota Dumai yang berada di pesisir pantai timur dari Sumatera khususnya di bagian Kelurahan Tanjung Palas, Kecamatan Dumai Timur, Provinsi Riau masih belum mengetahui tentang cara instalasi panel surya hingga dapat digunakan menjadi sumber listrik alternatif untuk aquaponik. Selain itu masyarakat di Kelurahan Tanjung Palas, Kota Dumai mayoritas memiliki mata penghasilan nelayan(Arkham et al., 2020; Yaqin et al., 2020). Penghasilan nelayan sangat tergantung dengan hasil tangkapan yang musiman. Disisi lain, daerah pesisir laut merupakan daerah yang memiliki energi matahari yang baik (Akbar et al., 2019). Salah satu solusinya yaitu dengan adanya pelatihan dan edukasi terhadap instalasi penggunaan solar panel sebagai sumber energi terbarukan pada instalasi aquaponik.

Penggunaan solar panel telah banyak digunakan untuk mencukupi kebutuhan alat elektronik (Naibaho, 2019) dengan daya yang rendah. Sehingga panel surya perlu diterapkan di masyarakat luas. 
Penggunaan sistem aquaponik dengan konsep budidaya perikanan dan tanaman secara berlangsung ditambah sumber listrik panel surya dapat menjadikan kelompok masyarakat terampil menuju masyarakat yang mandiri secara finansial (Dwiyaniti et al., 2020). Berdasarkan paparan diatas perlu dilakukan kegiatan pengabdian kepada masyarakat untuk meningkatkan pengetahuan dan keterampilan dalam hal instalasi panel surya sebagai sumber energi listrik pada masyarakat Kelurahan Tanjung Palas, Kota Dumai. Tujuan dari pengabdian masyarakat yaitu untuk meningkatkan pemahaman tentang pengoperasian dan perawatan dari panel surya sehingga dapat mencukupi kebutuhan energi listrik pada aquaponik.

\section{METODOLOGI PENGABDIAN}

Pelaksanaan kegiatan edukasi pengenalan dan pelatihan pengoperasian dan perawatan panel surya diawali dengan adanya survey kelompok masyarakat perikanan yang membutuhkan pemberdayaan agar kelompok tersebut lebih baik. Proses survei dibantu pihak CSR PT PERTAMINA (Persero) RU II Dumai untuk mengidentifikasi dari permasalahan pada kelompok masyarakat yang membutuhkan. Kebutuhan energi listrik pada aquaponik untuk menekan nilai ekonomi dari kebutuhan listrik PLN penggunaan mesin yang ada pada sistem sirkulasi air pada aquaponik. Berdasarkan informasi dari kelompok masyarakat di Tanjung Palas Kota Dumai tersebut, kebutuhan energi listrik dari PLN sangat merugikan masyarakat karena penggunaan aquaponik digunakan untuk kepentingan kelompok sedangkan listrik yang dibutuhkan masih menginduk pada rumah warga terdekat. Solusi yang ditawarkan hasil dari diskusi permasalahan yaitu dengan adanya panel surya yang dapat mengurangi sumber energi listrik agar meningkatkan nilai ekonomi dari penggunaan sistem aquaponik karena pengurangan penggunaan energi listrik dari PLN. Namun disisi lain kelompok masyarakat mayoritas masih perlu pengetahuan tentang pengoperasian dan perawatan panel surya karena adanya ketidakmerataan tentang pengetahuan solar panel sebagai sumber energi listrik. Edukasi pengenalan, pengoperasian dan perawatan dari solar panel sangat perlu di lakukan untuk meningkatkan pemahaman tentang penggunaan dan perawatan solar panel. Kegiatan ini berpotensi untuk menumbuhkan kesadaran masyarakat tentang pentingnya perkembangan ilmu pengetahuan dan teknologi yang efektif, efisien dan berkelanjutan.

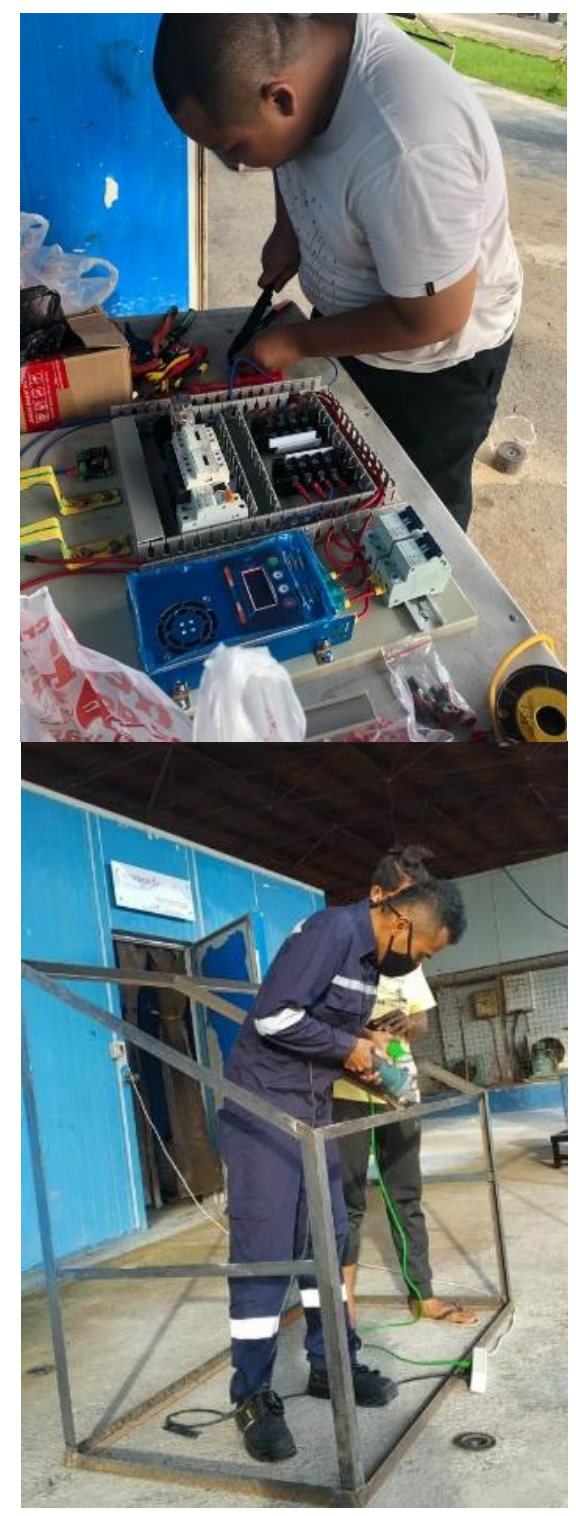

Gambar 1. Instalasi dan pembuatan dudukan panel surya

Rancangan kegiatan pengabdian kepada masyarakat dirancang dengan menggunakan metode pengembangan masyarakat. Rancangan kegiatan dilakukan dengan penyelesaian permasalahan persoalan yang ada. Penyelesaian permasalahan menggunakan pelatihan berupa pengenalan teori dan pelatihan secara langsung atau praktik. Langkah kegiatan setelah pendekatan masalah dan pemberian solusi yaitu persiapan alat dan bahan yang digunakan untuk pelatihan. Persiapan alat solar panel berupa rancangan instalasi panel, pembuatan dudukan dan instalasi solar panel dilakukan di workshop 
Permesinan Kapal Politeknik Kelautan dan Perikanan Dumai. Instalasi panel dan pembuatan dudukan solar panel ditunjukkan oleh Gambar 1.

Proses setelah pembuatan alat dan bahan untuk praktik yaitu proses pelatihan dengan ceramah secara teori dan praktik langsung mengoperasikan dan merawat dari solar panel. Rencana evaluasi pada kegiatan edukasi ini yaitu menggunakan proses pretest sebelum ceramah dan post-test sesudah ceramah dan kegiatan praktik langsung. Evaluasi pre-test dan post-test dilakukan untuk mengetahui kepahaman dari peserta. Hasil dari pre-test dan post-test akan disajikan menggunakan grafik sehingga pelaksana dapat mengetahui serapan peserta dalam memperhatikan materi. Penggunaan survei kepuasan terhadap kegiatan juga perlu disajikan dengan mengisi form survei sehingga hasilnya disajikan menggunakan grafik untuk memperoleh indeks kepuasan peserta akan terhadap kegiatan yang berlangsung.

Kegiatan pengabdian masyarakat edukasi solar panel sebagai sumber listrik aquaponik ini direncanakan di lingkungan Kelompok Nelayan Tuna di kelurahan Tanjung Palas, Kecamatan Dumai Timur Kota Dumai.. kegiatan pengabdian masyarakat ini diselenggarakan atas dasar dari kegiatan CSR PT PERTAMINA RU II Dumai.

\section{PELAKSANAAN KEGIATAN}

Pelaksanaan kegiatan pengabdian kepada masyarakat edukasi dan pelatihan solar panel sebagai sumber listrik aquaponic merupakan sebuah gagasan hasil kajian referensi yang diimplementasikan kepada masyarakat. Hasil kajian referensi tersebut ditunjukkan untuk memberikan solusi alternatif yang ditawarkan kepada kelompok masyarakat guna mengurangi kebutuhan energi listrik PLN untuk menjalankan sistem aquaponik. Hasil kajian referensi dilakukan oleh dosen di Politeknik Kelautan dan Perikanan Dumai. Produk hasil penerapan pengetahuan tersebut disajikan menjadi teknologi yang siap pakai dan dapat digunakan oleh masyarakat. Penerapan teknologi untuk masyarakat dapat diimplementasikan menjadi sebuah program pengabdian kepada masyarakat. Program pengabdian masyarakat berupa penerapan teknologi merupakan langkah untuk mengetahui pendapat masyarakat untuk masuknya teknologi yang baru.

Kegiatan edukasi solar panel sebagai sumber listrik pada sistem aquaponik beriringan dengan pembuatan aquaponik untuk budidaya lele dan tanaman pakcoy. Pemilihan budidaya ikan lele dan tanaman pakcoy dikarenakan lingkungan dan kondisi yang cocok di daerah tersebut. Disisi lain adanya salah satu komponen berupa pompa sirkulasi air pada sistem aquaponik dibutuhkan energi listrik AC untuk menghidupkannya. Oleh karena itu panel surya merupakan teknologi yang tepat untuk mengatasinya. Kegiatan pengabdian masyarakat di kelurahan Tanjung Palas, Kota Dumai bertujuan untuk memberikan pengetahuan bagaimana instalasi sistem solar panel pada sistem aquaponik dan memberikan pelatihan untuk mengoperasikan dan merawat solar panel secara berkala. Kegiatan pengabdian masyarakat ini dilaksanakan di salah satu tempat tinggal penduduk yang diperuntukkan sebagai tempat berkumpulnya kelompok masyarakat KUB Nelayan Tuna di kelurahan Tanjung Palas, Dumai Timur, Kota Dumai Provinsi Riau.

Penyelenggaraan pengabdian masyarakat dilaksanakan sesuai dengan jadwal dan rencana yang sudah dibahas oleh tim Politeknik Kelautan dan Perikanan Dumai dan tim CSR Pertamina RU II Dumai. Kegiatan yang sesuai rencana diharapkan agar kegiatan pengabdian kepada masyarakat berjalan dengan lancar, efektif dan efisien. Hal tersebut dikarenakan keterbatasan waktu warga dengan penyelenggara. Pelaksanaan kegiatan edukasi panel surya sebagai sumber listrik sistem aquaponik memiliki empat tahapan. Empat tahapan tersebut dikarenakan permintaan warga dilapangan secara mendadak agar warga lebih paham. Keempat tahapan tersebut antara lain

1. Persiapan

2. Materi pengenalan

3. Pelaksanaan instalasi dan praktek panel surya

4. Diskusi dan pemberian masukan

Kegiatan persiapan dilakukan dengan mempersiapkan alat dan bahan yang sudah disiapkan dan diangkut ke lokasi tujuan kegiatan pengabdian kepada masyarakat. Kegiatan ini bertujuan untuk mempersiapkan bahan paparan kepada masyarakat dan persiapan pemateri untuk mempresentasikan hasil dari kajian untuk menjadi solusi alternatif 
sumber energi pada aquaponik. Selain persiapan alat dan bahan yang digunakan, pada tahap ini digunakan untuk proses pendataan peserta dan absensi sehingga dapat peserta yang mengikuti dapat diarsipkan.

Kegiatan selanjutnya yaitu kegiatan materi pengenalan dengan metode ceramah yang ditunjukkan pada Gambar 2. Media bantu pemateri saat menyajikan materi di lapangan yaitu dengan memberikan pamflet yang sudah disediakan agar masyarakat sebagai peserta juga memiliki dokumen materi yang diajarkan. Peserta sangat antusias dari diskusi dari pemateri yang dibawakan oleh salah satu dosen Politeknik Kelautan dan Perikanan Dumai dengan didampingi tim CSR PT PERTAMINA RU II Dumai. Penyampaian materi teori di durasikan sekitar 1 jam agar peserta memiliki waktu untuk diskusi dengan pemateri. Sedangkan untuk materi yang disampaikan yaitu materi tentang pengetahuan panel surya sebagai energi listrik pada aquaponik, cara pengoperasian hingga cara perawatan panel surya ketika masih bekerja di sistem aquaponik.

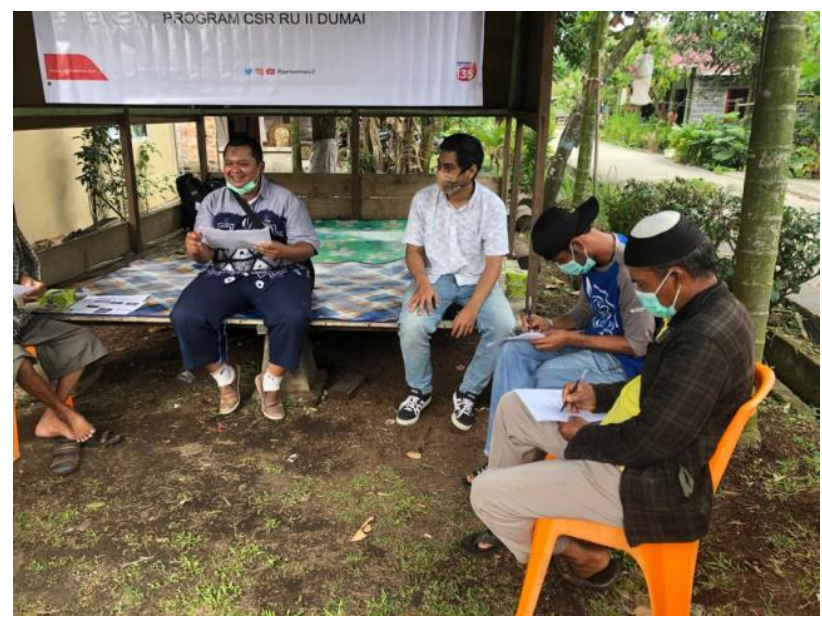

Gambar 2. Penyampaian materi panel surya secara teori

Kegiatan selanjutnya yaitu pengenalan komponen secara langsung dengan ditunjukkan pada Gambar 3 (a). Tujuan pengenalan komponen langsung kepada peserta agar mengetahui fungsi dan dapat menerapkan pengetahuan tersebut saat mengoperasikan dan merawat panel surya. Pengenalan komponen ini dikenalkan dengan penjelasan komponen dan rangkaian kepada masyarakat. Selanjutnya peserta diberikan kesempatan untuk mencoba secara langsung agar peserta lebih memahami dan dapat diaplikasikan ke tahap selanjutnya. Setelah kegiatan pengenalan komponen maka peserta diberikan pengetahuan untuk cara pengoperasian pada panel box dan perawatan pale surya yang ditunjukkan pada Gambar 3 (b). Kegiatan ini adalah kegiatan inti untuk mengenalkan dan meningkatkan pengetahuan peserta terhadap panel surya sehingga peserta dapat mengoperasikan sendiri panel surya pada aquaponik. Selanjutnya materi perawatan panel surya dilakukan secara praktek langsung yang ditunjukkan Gambar 4. Perawatan panel surya dilakukan dengan mengelap dengan kanebo basah dan menghilangkan debu dan kotoran yang menghambat yang mengurangi efisiensi dari panel surya. Selain itu pengecekan kabel penghubung pada panel surya perlu juga diperhatikan. Kegiatan bertujuan untuk memperpanjang umur panel surya. Durasi kegiatan ini yaitu 3 jam dan dilanjutkan sesi tanya jawab secara langsung untuk keguanaan pada langkahlangkah pada kegiatan tersebut.

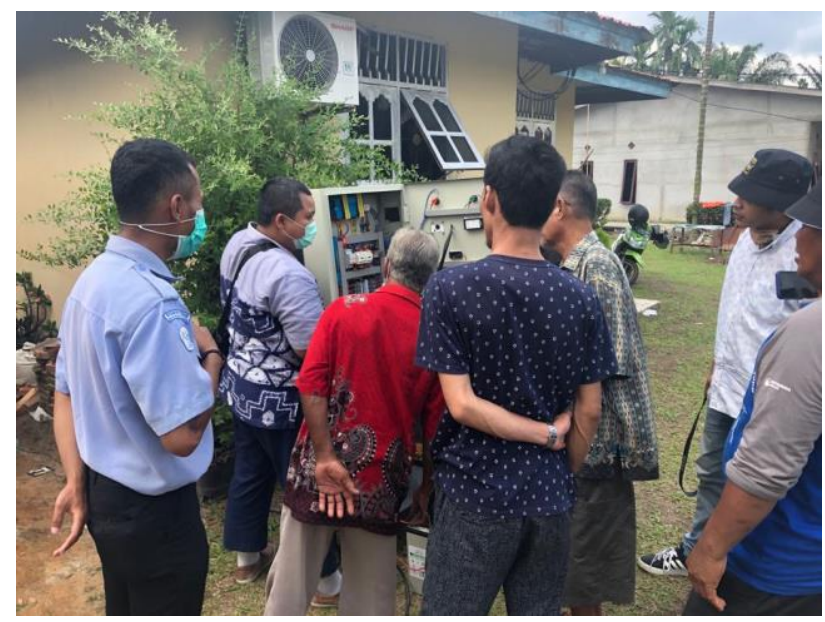

(a)

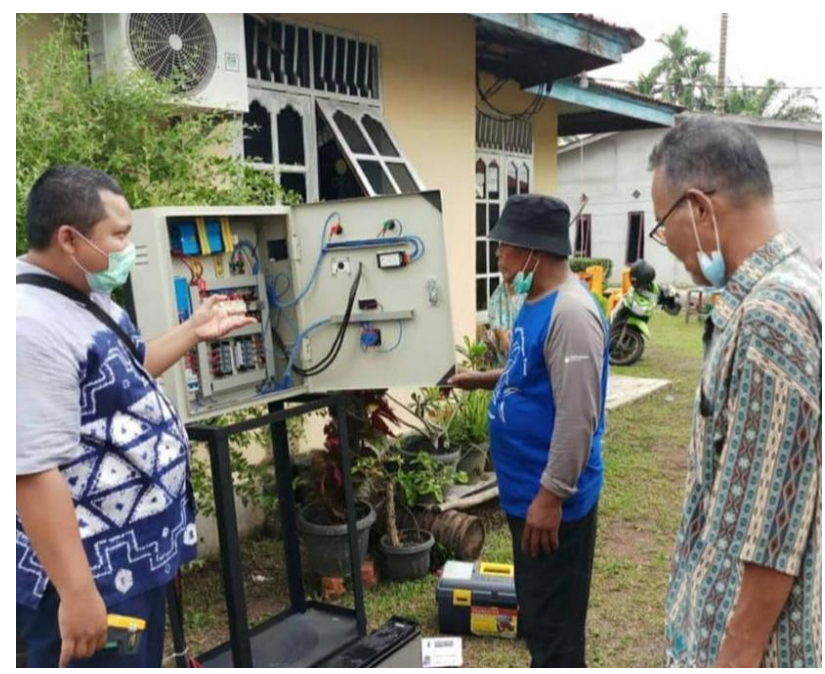

(b)

Gambar 3. Proses pengenalan komponen secara langsung (a) dan praktek langsung oleh peserta (b) 
Kegiatan terakhir yaitu sesi tanya jawab oleh peserta terhadap pemateri tentang kegiatan solar panel sebagai energi listrik alternatif pada sistem aquaponik. Selain itu pada kegiatan terakhir pelaksana kegiatan pengabdian kepada masyarakat yaitu pembagian kuesioner tentang pemahaman peserta dan tingkat kepuasan peserta atas kegiatan pengabdian ini. Hasil dan analisa kegiatan tersebut nantinya akan disajikan dalam grafik dan dibahas. Kegiatan berakhir di sore hari dengan penutupan dari tim CSR PT Pertamina RU II Dumai dan penutupan dari tim Politeknik Kelautan dan Perikanan Dumai.

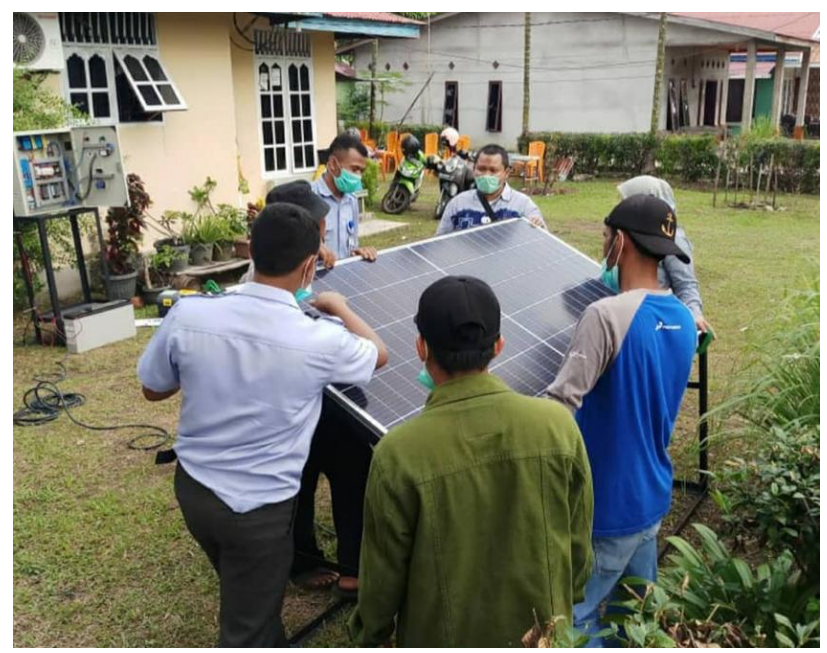

Gambar 4. Proses perawatan panel surya

\section{HASIL DAN PEMBAHASAN}

Identifikasi masalah pada masyarakat di Kelurahan Tanjung Palas, Kota Dumai terutama pada sektor kelautan dan perikanan yaitu belum adanya alternatif pekerjaan para nelayan ketika belum memasuki masa penangkapan operasi ikan. Budidaya aquaponik merupakan salah satu upaya masyarakat perikanan untuk memberikan penghasilan tambahan sehingga masyarakat tidak hanya menggantungkan kehidupan dari hasil nelayan. Namun disisi lain aquaponik merupakan salah satu sistem budidaya tanaman dan ikan dengan memanfaatkan siklus penggunaan air. Siklus penggunaan air pada aquaponik memerlukan mesin sirkulasi air agar air tersebut tetap berada pada sistem aquaponik. Di sisi lain kebutuhan energi listrik pada sistem aquaponik sangat perlu namun untuk mengurangi ketergantungan dan menurunkan pembiayaan listrik terhadap penggunaan listrik PLN dapat disolusikan dengan pemanfaatan energi terbarukan. Energi terbarukan yang dapat dimanfaatkan pada kondisi dan letak lokasi tersebut yaitu energi matahari. Oleh karena itu masyarakat di Kelurahan Tanjung Palas berharap dapat dibantu untuk menyelesaikan masalah tersebut.

Panel surya merupakan salah satu mesin konversi energi yang dapat menghasilkan energi listrik dari energi matahari. Penggunaan panel pada masyarakat pesisir sangat diperlukannya pendampingan maupun edukasi. Berdasarkan diskusi, survei dan musyawarah makan edukasi pengoperasian dan perawatan panel surya sebagai sumber energi listrik sistem aquaponik perlu di lakukan masyarakat perikanan di Kelurahan Tanjung Palas Kota Dumai. Kegiatan edukasi panel surya sebagai energi listrik pada sistem aquaponik dapat menajdi salah satu alternatif masyarakat tentang kebutuhan energi listrik pada sistem aquaponik sehingga masyarakat dapat mandiri terhadap penggunaan panel surya sebagai sumber energi listrik pada sistem aquaponik.

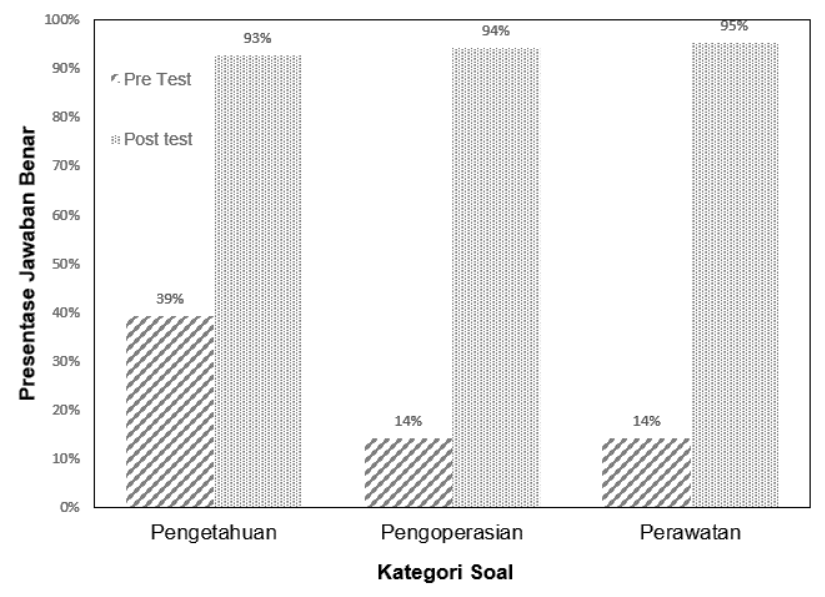

Gambar 5. Hasil kuesioner peserta pelatihan

Kuesioner terhadap peserta pelatihan menjadi salah satu media para penyelenggara untuk mengetahui tingkat pemahaman peserta pelatihan. Kuesioner pada edukasi pelatihan penggunaan panel surya sebagai sumber energi listrik dibagi menjadi beberapa kategori sehingga penyelenggara dapat mengetahui tingkat pemahaman di beberapa aspek. Hasil kuesioner yang telah dihasilkan dapat ditunjukkan pada Gambar 4. Peningkatan ditunjukkan pada grafik dari setiap kategori yang disampaikan pada kuesioner tersebut. Kategori pengetahuan meningkat dari $39 \%$ peserta menjadi $93 \%$ peserta, kategori pengoperasian meningkat dari $14 \%$ peserta 
menjadi $94 \%$ dan kategori perawatan meningkat dari $14 \%$ peserta menjadi $95 \%$ peserta. Hal tersebut menunjukkan adanya kebermanfaatan dari kegiatan pengabdian kepada masyarakat berupa edukasi sumber listrik alternatif panel surya pada sistem aquaponik. Peningkatan tersebut menjadi salah satu indikator dari keberhasilan kegiatan yang dilaksanakan. Selain itu juga, hasil kuesioner terebut menjadikan acuan untuk penyelenggara kegiatan untuk memperbaiki kendala-kendala yang ada. Selain kuesioner penyelenggara juga menghimpun pendapat peserta dan masyarakat dalam tingkat kepuasan adanya kegiatan pengabdian kepada masyarakat ini. Hasil dari penghimpunan pendapat tersebut dapat ditunjukkan oleh Gambar 5. Hasil diagram pie tersebut menunjukkan $25 \%$ peserta memiliki tingkat kepuasan sangat puas, sedangkan $75 \%$ peserta memiliki tingkat kepuasan puas dan tidak ada pada peserta pada kegiatan ini tidak memiliki kepuasan tidak puas/ sangat tidak puas. Hasil tersebut menunjukkan keberhasilan pelaksanaan kegiatan pengabdian ini. Namun, masih perlu adanya peningkatan beberapa tahapan untuk mengatasi kendala-kendala teknis. Selain itu juga hasil dari tingkat kepuasan tersebut menunjukkan perlu adanya persiapan yang lebih matang lagi dari kegiatan pengabdian masyarakat lainnya.

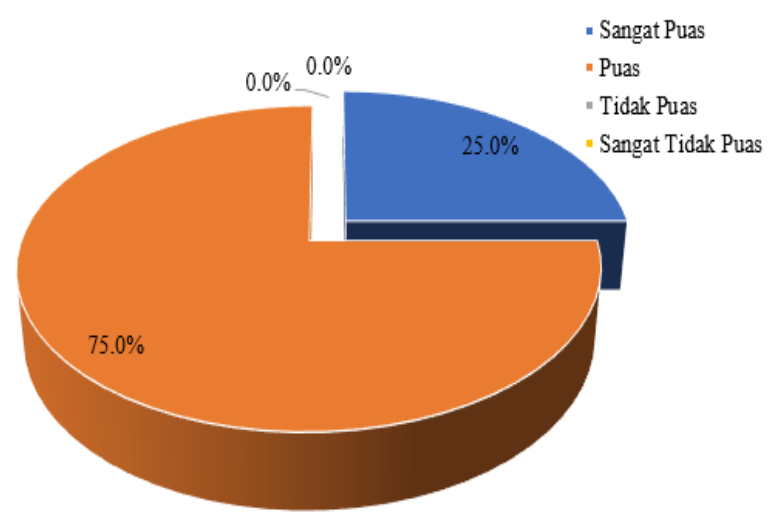

Gambar 6. Tingkat kepuasan peserta

Berdasarkan hasil analisa tingkat pemahaman, tingkat kepuasan dan hasil diskusi yang dilakukan dengan masyarakat menunjukkan perlu adanya acara keberlanjutan dari kegiatan pengabdian masyarakat seperti halnya kegiatan monitoring. Kegiatan monitoring bertujuan untuk mengetahui tingkat kemandirian masyarakat dalam mengelola panel surya sehingga dapat meningkatkan taraf ekonomi dari masyarakat. yang dituju. Kegiatan pengabdian masyarakat oleh Politeknik Kelautan dan Perikanan Dumai dan CSR PT Pertamina RU II Dumai menunjukkan kebermanfaatan kelompok masyarakat yang dituju. Sehingga perlu adanya kegiatan-kegiatan pengabdian masyarakat lainnya untuk dapat mendukung keberlangsungan masyarakat yang mandiri.

\section{PENUTUP}

\section{Kesimpulan}

Kegiatan pengabdian kepada masyarakat berupa edukasi solar panel sebagai sumber listrik pada sistem aquaponik berjalan dengan lancar dan sesuai rencana. Berdasarkan hasil yang didapatkan tingkat pemahaman peserta pada semua kategori memiliki kenaikan. Kategori pengetahuan meningkat dari 39\% peserta menjadi $93 \%$ peserta, kategori pengoperasian meningkat dari $14 \%$ peserta menjadi $94 \%$ dan kategori perawatan meningkat dari $14 \%$ peserta menjadi $95 \%$ peserta. Selain tingkat pemahaman, tingkat kepuasan pada kegiatan ini yaitu $25 \%$ sangat puas dan $75 \%$ puas atas kegiatan yang berlangsung. Hasil rekomendasi dari kegiatan pengabdian kepada masyarakat yaitu adanya tindak lanjut sehingga masyarakat dapat mandiri dalam melakukan kegiatan aquaponik.

\section{Saran}

Pengabdian kepada masyarakat yang telah dilakukan perlu disarankan untuk ditindaklanjuti agar peserta yang mengikuti dapat menerapkan nya. Selain itu kegiatan monitoring dan evaluasi terhadap kegiatan tersebut perlu ada karena untuk mengetahui peserta dapat menjalankan pelatihan yang sudah diberikan. Hal tersebut agar hasil dari kegiatan pengabdian ini dapat diterapkan secara berkelanjutan dalam kehidupan sehari-hari.

\section{DAFTAR PUSTAKA}

Akbar, A. W., Hiron, N., \& Nadrotan, N. (2019). Perencanaan Sistem Pembangkit Listrik Dengan Sumber Energi Terbarukan (Homer) Di Daerah Pesisir Pantai Pangandaran. Journal of Energy and Electrical Engineering, 1(1), 1218 . 
Arkham, M. N., Rizqy, F. M., Hutapea, R. Y., \& Yaqin, R. I. (2020). Pelatihan Penggunaan Fish Finder Untuk Peningkatan Produksi Perikanan Kelompok Nelayan Tuna Dumai. Warta Pengabdian, 14(4), 240.

Dwiyaniti, M., Riandini, \& Supriyono, E. (2020). Pemanfaatan Solar Sel dan Budidaya Perikanan Sebagai Upaya Menuju Kemandirian Finansial di Sekolah KAMI Utilization of Solar Cells and Fisheries Culture as Efforts Towards Financial Independence in Sekolah KAMI. Jurnal Panrita Abdi, 4(2), 146-154.

Ekawita, R., Supiyati, S., \& Yuliza, E. (2020). Peningkatan Skill dan Pengetahuan Masyarakat tentang Instalasi Panel Surya sebagai Sumber Energi Listrik Alternatif. PengabdianMu: Jurnal Ilmiah Pengabdian Kepada Masyarakat, 6(1), 44-47.

Hindarti, F. (2018). Otomatisasi Sirkulasi Air Pada Instalasi Aquaponik Dengan Panel Surya (Solar Cell) Sebagai Sumber Energi Alternatif. Jurnal Teknologi Technoscientia, 11(1), 29-38.

Jufrizel, \& Irfan, M. (2017). Perencanaan Teknis dan Ekonomis Pembangkit Listrik Tenaga Surya Sistem On-Grid. Seminar Nasional Teknologi Informasi, Komunikasi Dan Industri (SNTIKI) 9, 430-436.

Mcneil, M. A., Karali, N., \& Letschert, V. (2019). Energy for Sustainable Development Forecasting Indonesia' $\mathrm{s}$ electricity load through 2030 and peak demand reductions from appliance and lighting ef fi ciency. Energy for Sustainable Development, 49, 65-77.

MEMR (Ministry of Energy and Mineral Resources of the Republic of Indonesia). (2016). Handbook ofenergy \& economic statistics of Indonesia. In MEMR.

Naibaho, N. (2019). Efisiensi solar panel sebagai alternatif sumber energi. Seminar Nasional Teknologi, 139-147.

Pavlović, T., Milosavljević, D., Radonjić, I., Pantić, L., Radivojević, A., \& Pavlović, M. (2013). Possibility of electricity generation using PV solar plants in Serbia. Renewable and Sustainable Energy Reviews, 20, 201-218.

Pringle, A. M., Handler, R. M., \& Pearce, J. M. (2017). Aquavoltaics: Synergies for dual use of water area for solar photovoltaic electricity generation and aquaculture. Renewable and Sustainable Energy Reviews, 80(December 2016), 572-584.

Stevović, I., Mirjanić, D., \& Stevović, S. (2019). Possibilities for wider investment in solar energy implementation. Energy, 180, 495-510.

Tarigan, E., Djuwari, \& Purba, L. (2014).
Assessment of PV Power Generation for Household in Surabaya Using SolarGIS pvPlanner Simulation. Energy Procedia, 47, 85-93.

Umar, M. L., \& Yaqin, R. I. (2020). Studi Numerik Dengan Model Empat Parameter Untuk Memprediksi Daya Luaran Dari Panel Surya. Infotekmesin, 11(2), 125-129.

Yaqin, R. I., Ziliwu, B. W., Demeianto, B., Siahaan, J. P., Musa, I., Priharanto, Y. E., Efendi, R., Rozaki, M. A., Hasibuan, N. E., \& Arkham, M. N. (2020). Edukasi Perawatan Motor Diesel Kapal Nelayan Desa Pelintung Kota Dumai. Warta Pengabdian, 14(3), 200. 